\begin{tabular}{l|l|l|}
\cline { 2 - 3 } CRITICAL & $\begin{array}{l}\text { Western Ghats } \\
\text { SPARTNERSHEM }\end{array}$ \\
\cline { 2 - 3 } & Special Series \\
\hline
\end{tabular}

\section{AN ENDEMIC AND CRITICALLY ENDANGERED SPECIES, GYMNEMA KHANDALENSE SANTAPAU (APOCYNACEAE: ASCLEPIADOIDEAE) - A NEW RECORD TO GOA STATE, INDIA}

Subhash S. Deokule ${ }^{1}$, Shrinath P. Kavade ${ }^{2}$, P. Lakshminarasimhan ${ }^{3} \&$ Vikrant B. Berde ${ }^{4}$

${ }^{1}$ Department of Botany, University of Pune, Ganeshkhind, Pune Maharashtra 411007, India

${ }^{2}$ Department of Botany, ${ }^{4}$ Department of Zoology,

Arts, Commerce and Science College (ACS), Lanja, Ratnagiri District, Maharashtra, India

${ }^{3}$ Central National Herbarium, Botanical Survey of India, P.O. Botanic Garden, Howrah, West Bengal 711103, India

${ }^{1}$ deokule@unipune.ernet.in, ${ }^{2}$ shrinathkavade@gmail.com,

${ }^{3}$ lakshminarasimhanp@yahoo.co.in (corresponding author), ${ }^{4}$ vberde@yahoo.com

Anjunem Lake is located on Sanquelim-Belgaum Highway in the northern Goa District of Goa State. It lies between $15^{\circ} 36^{\prime} 56^{\prime \prime} \mathrm{N} \& 74^{\circ} 05^{\prime} 21^{\prime \prime} \mathrm{E}$ and situated at an elevation of $121 \mathrm{~m}$. During the floristic exploration of Keri-Satteri forests of Goa State, one of us (SPK) collected Gymnema khandalense Santapau (Apocynaceae: Asclepiadoideae), hitherto not recorded from Goa State (Rao 1986; Naithani et al. 1997). The genus Gymnema R. $\mathrm{Br}$. is represented by 14 species and two varieties in India (Karthikeyan et al. 2009). This species was described by Santapau based on his collections from Khandala (Pune District) in 1949 and since then it has not been collected from the type locality. This endemic species was thought to be quite rare and possibly extinct (Sundararaghavan
\& Singh 1983, 1984). However, Kothari \& Moorthy (1983) collected it from Masadi forest, Roha, Raigad District, Maharashtra after a lapse of 34 years. Subsequently, Sasidharan \& Swarupanandan (1994) reported its extended distribution in Kerala from Vazhachal forests in Thrissur

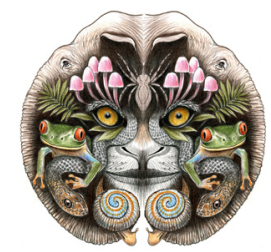

ISSN

Online 0974-7907 Print 0974-7893

\section{OPEN ACCESS} District. Yadav \& Sardesai (2002) recorded itfrom Panhala, Kolhapur District of Maharashtra. Recently, Udayan et al. (2004) reported it from another place in Kerala, from Nilakkal forests, Pathanamthitta District. This species has been categorized as rare by Kothari (1990) and Walter \& Gillett (1998), Critically Endangered by Mishra \& Singh (2001) and Vulnerable (Sundararaghavan \& Singh 1984; Sardesai et al. 2006). Since it forms a new record to Goa State, a brief description, phenology, and distribution along with a photo plate has been provided to facilitate its easy identification.

\section{Gymnema khandalense}

Santapau in Kew Bull. 1948: 486. 1949 \& in Rec. Bot. Surv. India 16(1): 172. 1953; Santapau \& Irani in Bot. Mem. Univ. Bombay 4: 49. 1962; Kothari \& Moorthy in J. Bombay Nat. Hist. Soc. 80: 259. 1983; Sasidh. \& Swarupanan. in J. Econ. Taxon. Bot. 18: 633. 1994; M.R. Almeida, Fl. Maharashtra 3(A): 245. 2003; Karthik. \& al., FI. PI. India - Dicotyl. 1: 171. 2009. Bidaria khandalensis (Santapau) A.P. Jagtap \& N.P. Singh in Biovigyanam 16: 62. 1990, in J. Econ. Taxon. Bot. 22: 232. 1998 \& in Fasc. Fl. India 24: 67. 1999; Kothari \& Moorthy, Fl. Raigad Distr.: 237, f. 1993; D.K. Mishra \& N.P. Singh, End. Threat. FI. PI. Maharashtra: 126. 2001; A.P. Jagtap \& Das Das in

DOI: http://dx.doi.org/10.11609/JoTT.03438.4598-600

Editor: N.P. Balakrishnan, Ret. Joint Director, BSI, Coimbatore, India

Date of publication: 26 July 2013 (online \& print)

Manuscript details: Ms \# 03438 | Received 09 June 2011 | Final received 18 May 2013 | Finally accepted 08 July 2013

Citation: Deokule, S.S., S.P. Kavade, P. Lakshminarasimhan \& V.B. Berde (2013). An endemic and Critically Endangered species, Gymnema khandalense Santapau (Apocynaceae: Asclepiadoideae) - a new record to Goa State, India. Journal of Threatened Taxa 5(11): 4598-4600; http://dx.doi.org/10.11609/JoTT.o3438.4598600

Copyright: ( D Deokule et al. 2013. Creative Commons Attribution 3.0 Unported License. JoTT allows unrestricted use of this article in any medium, reproduction and distribution by providing adequate credit to the authors and the source of publication.

Funding: No funds were provided by any agency.

Competing Interest: None.

Acknowledgements: We thank Dr. Sudhir R. Bhosale, Principal, ACS College, Lanja and Director, Botanical Survey of India, for facilities. Thanks are also due to Goa Forest Department, for the help rendered during the field work in Keri-Sateri forest and to Dr. W. Arisdason, Botanical Survey of India, Kolkata, for going through the paper critically.

The publication of this article is supported by the Critical Ecosystem Partnership Fund (CEPF), a joint initiative of l'Agence Française de Développement, Conservation

International, the European Commission, the Global Environment Facility, the Government of Japan, the MacArthur Foundation and the World Bank. 
N.P. Singh et al., Fl. Maharashtra State - Dicot. 2: 337. 2001; Sardesai et al. in Indian J. Forest. 29: 181. 2006.

A large woody climber. Stems corky, winged at maturity, $6-8 \mathrm{~cm}$ across, pubescent when young; latex milky to yellowish-white. Leaves opposite, broadly elliptic-ovate, 8-12×7-9 cm, truncate at base, acuteacuminate at apex, sub-coriaceous, densely tomentose below. Flowers in axillary, umbellate cymes; peduncles c. $1 \mathrm{~cm}$ long; pedicels c. $7 \mathrm{~mm}$ long. Calyx lobes oblong, 1-1.4 mm long, acute at apex, pubescent at margins and outer surface, yellowish-green. Corolla campanulate, 3-3.5×1-1.3 mm, yellow; lobes triangular, ciliolate at margins, fleshy, pubescent inside. Corona 5, adnate, ridges slightly protruding to corolla tube, hairy. Pollinia yellow; corpusculum red. Gynostegium c. $2 \mathrm{~mm}$ long. Follicles lanceolate, $8-10 \times$ c. $0.5 \mathrm{~cm}$, densely pubescent, white-dotted.

Specimens examined: 11.iii.2012, SanquelimBelgaum Highway, Keri-Sateri Forests, Anjunem Lake, North Goa District, Goa, coll. S.P. Kavade, Reg. No. 651 (BSI and Herbarium of Department of Botany, University of Pune) (Images 1 \& 2).

Flowering and Fruiting: October-January.

Distribution: Endemic to Western GhatsMaharashtra: Kolhapur (Amba, Dajipur, Manoli, Panhala, Udegiri); Pune (Karli, Khandala); Raigad (Masadi Forest,
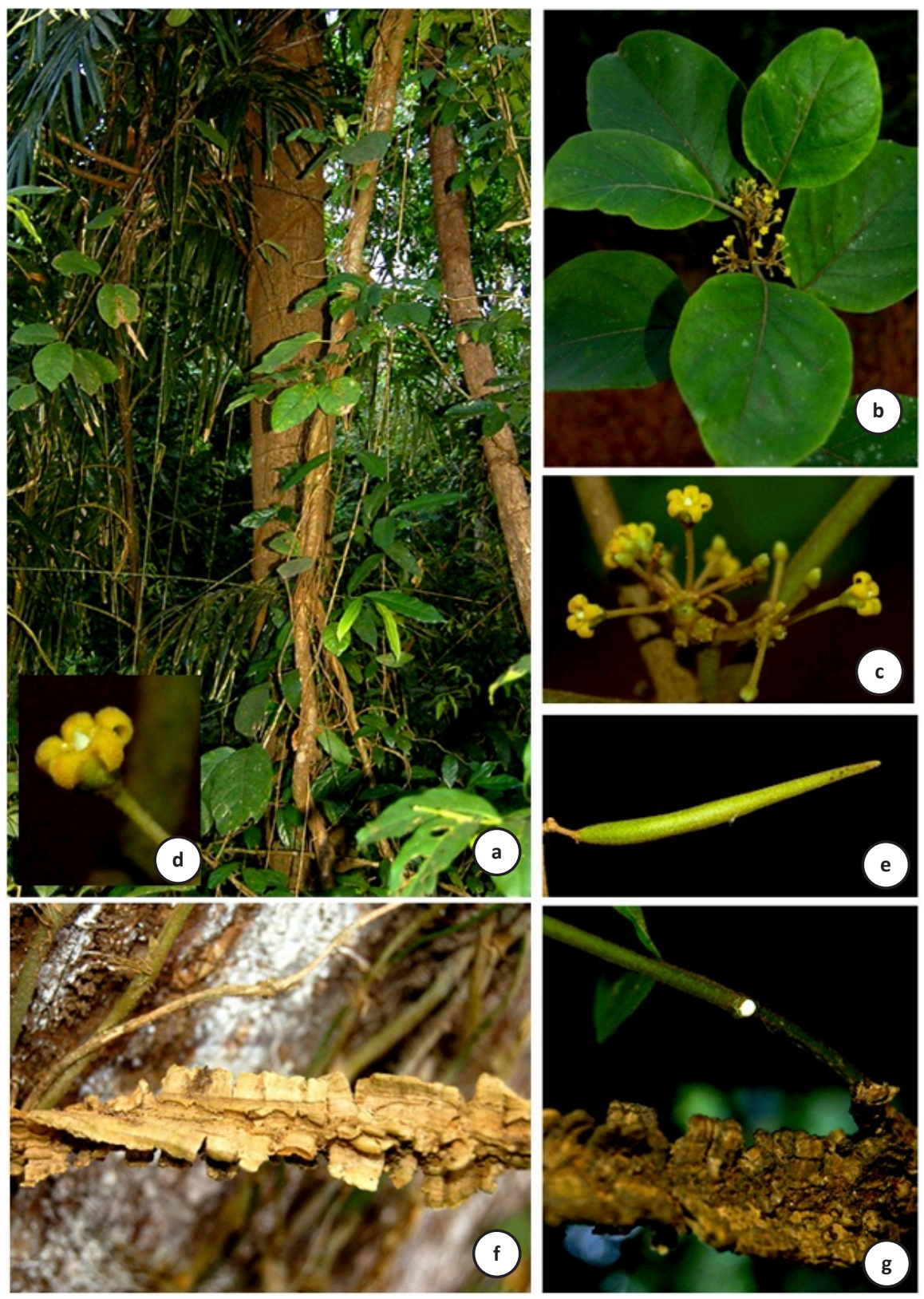

Image 1. Gymnema khandalense Santapau

a - Habitat; b - Flowering twig;

c - Inflorescence; d - Single flower;

e - Follicle; f - Corky bark; g - Yellowish milky latex. @ Shrinath P. Kavade 


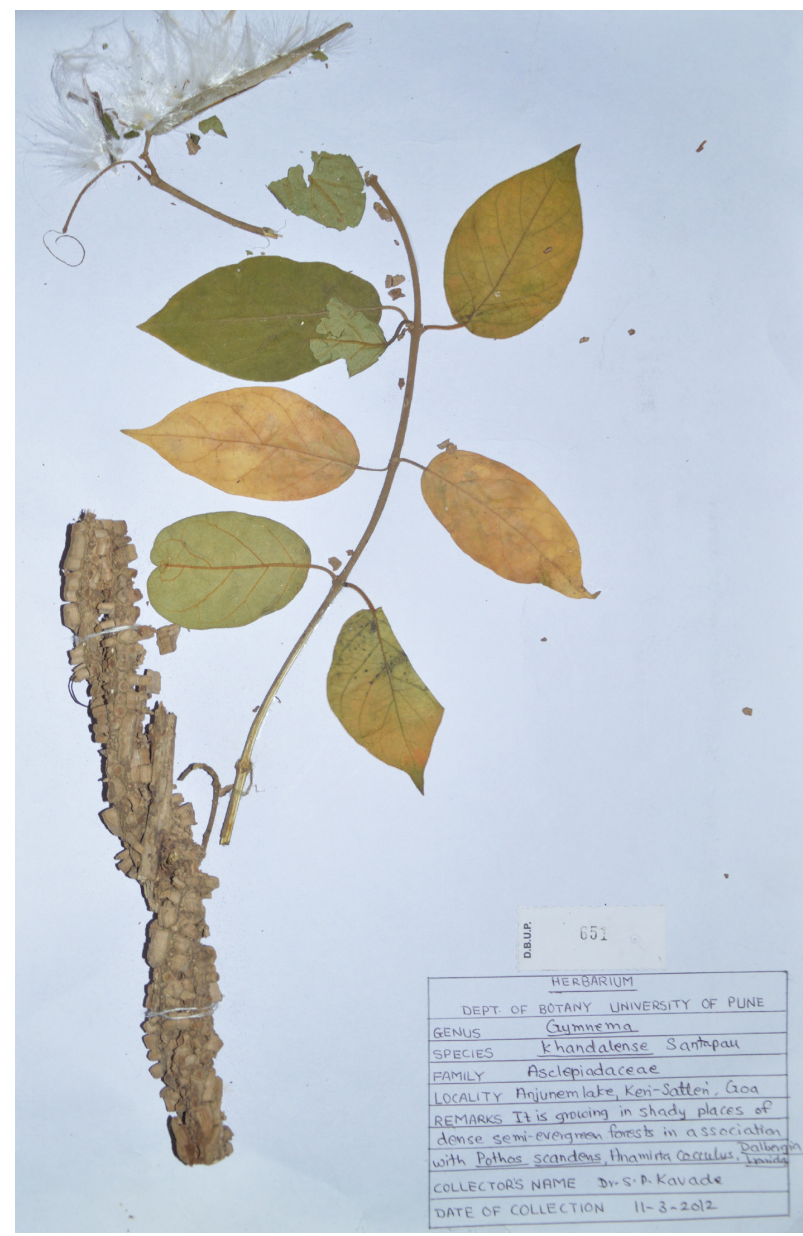

Image 2. Herbarium image

Roha); Ratnagiri (Maral-Marleshwar). Goa: Keri-Satteri forests. Kerala: Pathanamthitta (Nilakkal forests, near Sabarimala); Thrissur (Athirapally, Vazhachal) (Image 3).

Ecology: Growing at an elevation of about $120 \mathrm{~m}$ $\left(15^{\circ} 36^{\prime} 56^{\prime \prime} N \& 74^{\circ} 05^{\prime} 21^{\prime \prime} \mathrm{E}\right)$ in shady places of dense semi-evergreen forests climbing on Terminalia chebula Retz. along with Calamus thwaitesii Becc. Other associates are Pothos scandens L., Anamirta cocculus (L.) Wight \& Arn., Chonemorpha grandiflora (Roth) M.R. Almeida \& S.M. Almeida, Dalbergia horrida (Dennst.) Mabb., Ixora brachiata Roxb., Atalantia racemosa Wight and Combretum albidum G. Don.

A total of 10 mature individuals were observed.

\section{REFERENCES}

Karthikeyan, S., M. Sanjappa \& S. Moorthy (2009). Flowering Plants of India: Dicotyledons Volume 1 (Acanthaceae - Avicenniaceae). Botanical Survey of India, Kolkata, 170-171pp.

Kothari, M.J. (1990). Gymnema khandalense Santapau, pp. 37-38. In: Nayar, M.P. \& A.R.K. Sastry (eds.) Red Data Book of Indian Plants 3.

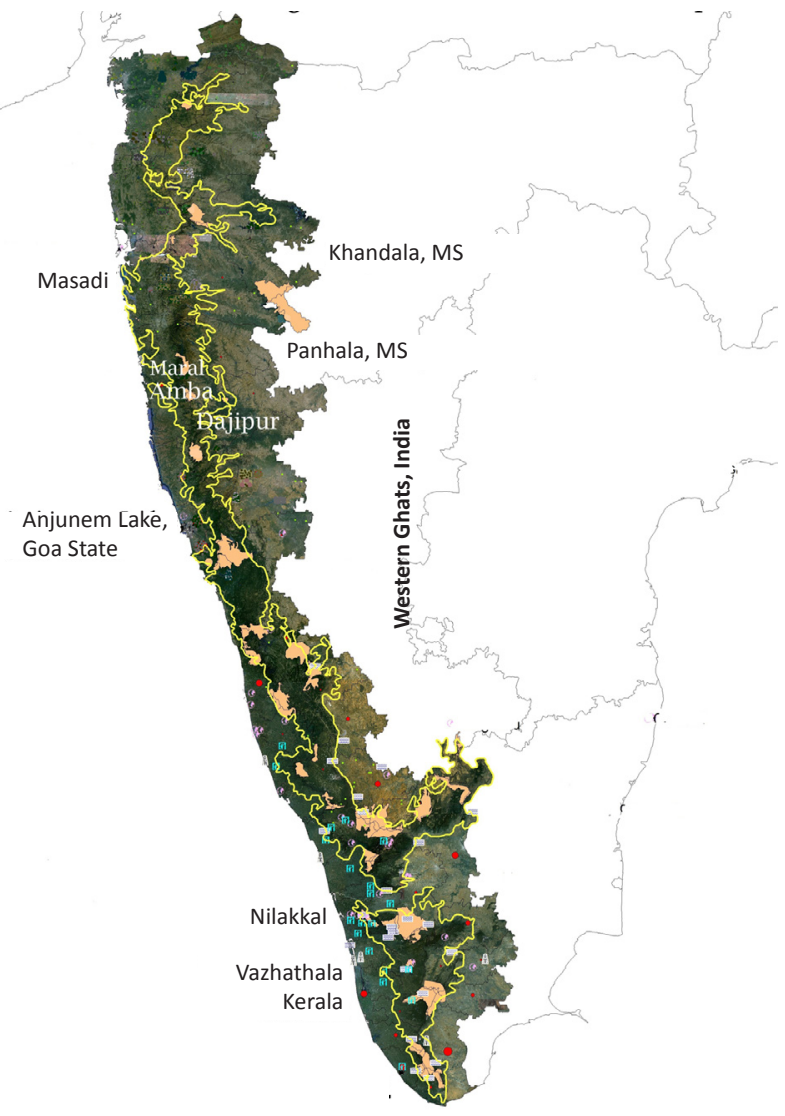

Image 3. Distribution map of Gymnema khandalense Santapau

Botanical Survey of India, Calcutta.

Kothari, M.J. \& S. Moorthy (1983). Some noteworthy plants from Kolaba District, Maharashtra State. Journal of the Bombay Natural History Society 80: 259-260.

Mishra, D.K. \& N.P. Singh (2001). Endemic and Threatened Flowering Plants of Maharashtra. Botanical Survey of India, Calcutta, 126$128 \mathrm{pp}$.

Naithani, H.B., K.C. Sahni \& S.S.R. Bennet (1997). Forest Flora of Goa. International Book Distributers, Dehra Dun, 666pp.

Rao, R.S. 1986. Flora of Goa, Diu, Daman, Dadra and Nagarhaveli - 2 Volume. Botanical Survey of India, Calcutta, 199-546pp.

Sardesai, M.M., S.P. Gaikwad \& M.Y. Kamble (2006). Notes on distribution, status and ex-situ conservation of Bidaria khandalense (Sant.) Jagtap \& Singh. (Asclepiadaceae). Indian Journal of Forestry 29: 181-185.

Sasidharan, N. \& K. Swarupanandan (1994). Discovery of some rare and interesting Asclepiads from Kerala. Journal of Economic and Taxonomic Botany 18: 631-637.

Sundararaghavan, R. \& N.P. Singh (1983). Endemic and Threatened plants of Western India. Plant Conservation Bulletin 3: 6.

Sundararaghavan, R. \& N.P. Singh (1984). An inventory of endemic and vulnerable species of western India deserving conservation. Journal of Economic and Taxonomic Botany 5: 153-164.

Udayan, P.S., K.V. Tushar, S. George \& I. Balachandran (2004). Gymnema khandalense Santapau - A rare and little known endemic red listed medicinal plant from Nilakkal forest, Kerala. Zoo's Print Journal 19(9): 1623-1624; http://dx.doi.org/10.11609/JoTT. ZPJ.1179.1623-4

Walter, K.S. \& H.J. Gillett (1998). 1997 IUCN Red List of Threatened Plants. IUCN, Gland, 67pp.

Yadav, S.R. \& M.M. Sardesai (2002). Flora of Kolhapur District. Shivaji University, Kolhapur, xiv+680pp. 